DOI https://doi.org/10.18551/rjoas.2018-08.33

\title{
THE ULTIMATE PROVISION OF BASED EROSION AND PROFIT SHIFTING ACTION PLAN FOR STEADY TAXATION IN INDONESIA
}

\author{
Kumalasari Kartika Putri*, Fadila Ciresta Adlina \\ Taxation Program, Faculty of Administrative Science, University of Brawijaya, Indonesia \\ *E-mail: kartikasari23@ub.ac.id
}

\begin{abstract}
Purpose of this study is explaining the basic form of Based Erosion and Profit Shifting (BEPS) and how to overcome it by using BEPS Action plan that is launched by OECD in Indonesia. The commonly faced challenge is the mismatch of tax regulation between countries and incorporating this factor in quantitative model can lead to its own complexity. Therefore, this study employed qualitative method aimed at explaining the unaccommodated problems by the previous method. The next limitation often considered as the obstacle is the limited availability and data access. Micro data source (including tax return and corporate tax audit data) essentially contains of important information to measure the practice of BEPS (Based Erosion and Profit Shifting) and to map the behavior of multinational company to identify the basic form of BEPS and the functions of the action plan of BEPS. The hybrid mismatch is on the implementation of different transactions by every country to avoid tax and provide special purpose entities (SPE) which gives freedom to MNCs to transfer business profit to other countries. A synergy between the government and taxpayers in understanding BEPS Action and in-depth study on the implementation in developing countries are essential. Developing Countries that have various forms of business and culture certainly cannot be accommodated with one standard of BEPS Action.
\end{abstract}

\section{KEY WORDS}

BEPS, action plan, international taxation, Indonesia.

Globalization is now entering a time where everything is getting closer and giving a more comprehensive view as a result of the international integrity process occurred due to the exchange of world views that lead to different thoughts and products and other cultural aspects. Increasingly, this world integration has resulted in a sequence of consequences from economic, political, cultural and environmental aspects. This opens up many opportunities to provide new potential for good and bad development, where true integration has the noble goal of a more prosperous expectation since the increased interaction among people also has the potential to increase global solidarity. On the other hand, globalization has the fear to be able to divide the unity because of the occurred conflict of interest (Wol, 2002).

Referring to the impact of globalization for the economy, international trade is no longer a strange phenomenon since all can be done so easily and quickly. The relationships among countries can be easily carried out so that the profits' impact can be doubled and the utility of the goods and services produced can be more extensive. The potential of business competition is progressively realized from its competitive power both in terms of the product manufacturing to pricing, competing to win market loyalty including in the taxation. The use of digital and business globalization lead to increasingly complex transaction schemes that pave the way for actors who play a role in the practice of erosion and profit shifting bases in making a diversion of profits.

It has its own challenge to interpret and measure the definition of Base Erosion and Profit Shifting (BEPS). In some cases, financial decisions included in BEPS action if it is only to reduce tax liabilities without a strong economic substance, since it is still difficult to distinguish which is the real business decisions and tax avoidance motives. In addition, it is essential to review the problem of model specifications because the model is so diverse that it can affect the form of profit transfer schemes used. The next arising problem is the multi- 
interpretation in understanding the scheme of the implemented measurement model. The common challenge is the mismatch of tax rules between countries, and incorporating these factors in a quantitative model can create its own complexity. Therefore, this study employed qualitative methods aimed at explaining the subject unaccommodated by the previous method. The next limitation is due to the lack of availability and data access. Micro data sources (such as tax return and corporate tax audit data) essentially contain important information used both to measure BEPS practices and to map the behavior of multinational companies. However, this process is hampered by limited access and confidentiality protected by Article 34 of the Indonesia's KUP Law (Visaro, 2017).

In the context of BEPS action plan where the allocation of tax rights should be in accordance with the value of jurisdiction created especially if it is associated with efforts to claim greater taxation rights to the profits derived by multinational corporations (Aeny, 2017). Similarly, the jurisdiction cases of BEPS in Hong Kong and Singapore are unique since both apply the lowest tax rate in order to attract other investors and influence competitive competition with other countries so that the tax system of the company correspondingly has a significant impact on the world economy especially in this era of digital economy and causes turmoil for other world communities due to the various understanding of BEPS.

Further discussion on the development of taxation issues in the international tax context has continued to increase in recent periods such as Panama Papers, Lux Leaks, Swiss Leaks to a significant amount of foreign profits from multinational companies such as Google, Microsoft, IBM and Apple and Amazon which has become a widespread discussion. The case was originated from the transfer pricing (TP) activities contained in the tax plan carried out as a preceding policy and tax administration. The multinational giant actors possibly step ahead the current tax regulations, obviously with the help of technology (Ngantung, 2016).

This BEPS discussion is closely related to the international tax principles of allocation of taxation rights that are increasingly obsolete in the era of digital economy. The challenges resulted from the increasing progress in information and communication technology (ICT) include issues of intangibles, business substance identification, calculation of tax base and so on. Basically, the challenge in formulating the right taxation policy in the digital era end up on three points. The first is nexus. Non-physical presence in business as well as commercial relationships with increasingly sophisticated networks create difficulties for defining business connections with certain jurisdictions. Second, the role of data is increasingly important in determining the success of digital business. In spite of its big role in the process of value creation, data collection activity, information management and its use to target the right consumer, however it is difficult to be measured. The last is the characterization of the income gained from the digital business model, for example, the debate over whether earnings are categorized as payments for technical services, operating profit, or royalties. In addition to redefining the Permanent Establishment (BUT), there are four options available to stakeholders. Another solution is defining a new nexus for a significant economic presence, followed by an allocation of income from an economic presence and withholding tax on digital business (DDTCNews, 2016).

Those several action plans specifically aimed at warding off the tax structure used by multinational companies in the digital economy comprising transfer pricing, hybrid mismatch, avoidance of CFC (Controlled Foreign Company) regulations, avoidance of BUT formation and utilization of preferential tax regime. Although BEPS Project has been on the right direction, in fact, the implementation of the recommendations is based on the discretion of each country. In other words, the OECD cannot issue binding regulations for all countries, but it is to the extent of providing soft law recommendations. Thus, although the BEPS Project recommendations are acknowledged to be highly relevant in addressing the taxation issues of the digital economy, as mentioned by the European Parliament's Special Committee, some recommendations of the BEPS Project are practically deemed unsuccessful in dealing with the core problem. In fact, some countries in fact issue taxation policies that are contrary to the recommendations of the BEPS Project, by creating new types of taxes specifically targeted to certain businesses of the digital economy. The 
example is diverted profits tax in England and Australia which is often crowned by media as Google Tax and Equalization Levy in India.

On the other hand, developments in the US need also to be considered. In contrast to the recommendations of the BEPS Project, Barack Obama's Government proposes to apply a minimum of $19 \%$ of the global earnings of US multinationals, regardless of whether the offshore profits has been repatriated or not. Obama's proposal is aimed at limiting aggressive tax planning practices by many US multinationals by placing offshore profit in tax haven countries or known as stateless jurisdiction countries. However, unlike Obama, the elected US President Donald Trump is planning to revoke the proposal of minimum tax and, as the alternative, he proposes to provide facilities for multinational companies by lowering tax rates for repatriation of its operating profits abroad. Again, this step also does not comply with the recommendations of the BEPS Project. Dissatisfaction on BEPS project is also shown by the EU Commission with the issuance of the Anti-Avoidance Directive (ATAD) proposal containing recommendations of regulations uncovered by the BEPS Project in the form of recommendation for General Anti Avoidance Rule (GAAR), switch over clause and exit taxation.

Furthermore, the EU Commission also announced plans to review the Common Consolidated Corporate Tax Base (CCCTB) project. This CCCTB project is a form of formulary apportionment approach which is contrary to the international consensus on the implementation of arm's length principle associated with the allocation of income between taxpayers in one group. All of the above developments show the growing importance of digital economic relevance in international taxation. The risks of this growing digital tax industry will certainly be unavoidable, including to developing countries. Thus, it is essential to accommodate the issues of digital economy taxation under simple, flexible, efficient international standards since the risk of the growing issue of tax in digital economy cannot be avoided including by developing country. This is what should be noted (Deep, 2016).

Moreover, this is also emphasized by Yansheng Zu, Tax Law Professor of Xiamen University, in the context of the case of transfer pricing. He argues that value creation in the action of BEPS 8-10 seems to rule out the contribution of developing countries on the profits of multinational companies. As suggested by Yansheng, this should be offset by value realization which takes into account the market factors that in the end determine the value of the product. A product can become more valuable when facing certain characteristic market. In the end, it is the market perception that determines how successful a product can be marketed. This explanation is in line with representatives from such other countries as Brazil and Italy (Vissaro, 2017).

According to the background of the study and supported by the formulation of the Millennium Development Goals proclaimed by the United Nations on the Making of a Global Relations for Development, particularly in the case of formulating the openness of rule, prediction and trading which is non-discriminatory and trading and financial improvement system. Due to the importance of this discussion, then the two formulated research problems to be investigated are:

- What is the basic form of Based Erosion and Profit Shifting (BEPS)?

- What is the function of an Action Plan Based on Erosion and Profit Shifting (BEPS)?

Both formulation of the above problems aims at identifying the basic form of Based Erosion and Profit Shifting (BEPS) and the function of Action Plan of Based on Erosion and Profit Shifting (BEPS).

Assisting the Government particularly developing countries to improve the Action Plan in addressing Based Erosion and Profit Shifting (BEPS) and run the program proclaimed by the United Nations in the Millennium Development Goals, specifically the eighth goal in its efforts to build global relationships for collective advancement by focusing on improving the financial system and clarity of the legal basis and open access. For Academics, of course, it can enrich the understanding, especially in the theoretical basis of Based Erosion and Profit Shifting (BEPS) so that both the government and society in general help to find solutions to the impact of Based Erosion and Profit Shifting (BEPS). 


\section{LITERATURE REVIEW}

In international tax, there is an agreement governing the taxation of the two contracting countries which agree on the tax limit of inputs from trade and investment during the business. So, international tax is an international aspect of income tax law of an individual country (Burns, 2017). Fundamentally, international tax focuses on the residents of foreign taxation and taxation of domestic income for non-residents. The next discussion deals with of International Tax.

BEPS may occur in multi-national companies involving the tax law of the two countries in relation to regulating the profit earned to remain optimal but still fulfill the tax obligation. Thus, transfer pricing activity can allocate the benefits gained to other places. So, BEPS focuses on developing a disconnect between the locations of the economy activity and the location where profit is gained (Burns, 2017). The complete explanation is presented in the discussion section.

\section{METHODS OF RESEARCH}

This research employed qualitative methods aimed at identifying the basic form of BEPS in accordance with scientific procedures (Keyton, 2006: 2). Qualitative method was chosen because it can reveal how social phenomenon in depth and perform holistic observations to gain a full understanding (Babbie 2014: 304).

Research focus is an important factor related to the problems and data collected, processed and analyzed. The focus of the study limits the object being studied in order to focus specifically on the studied elements, thus the resulting description is in accordance with the problems formulated. The purpose of formulating research focus (Moelong, 2004) is to explain the basic form of BEPS and the function of BEPS Action Plan and the meaning of the BEPS Action Plan agreed in the G-20.

Secondary data of this research is the form of secondary documents comprising article, journal and book on BEPS and others.

Data collection is a determinant of research success. Data collection is one of the procedures systematically to obtain the required data (Nazir, 2005). In qualitative research, data collection techniques related to the procedure/process of data recording in the field which includes:

- Observational protocol: the protocol is used to record the observed data. This protocol can be in the form of a sheet of paper used to record, descriptive notes or reflective notes. Descriptive notes include descriptions of participants or informants, reconstruction of dialogs, descriptions of physical settings, notes on specific events and activities. Reflective notes related to the personal knowledge of the researcher such as speculation, feelings, problems, ideas, guesses, impressions, and prejudices. In addition, this protocol may also include demographic information such as hours, dates, and the current location of the researcher.

- Documentation is a technique of collecting data by studying documents and files on institutions that are useful as inputs related to the subject. According to Hasan (2002), documents used are in the form of data that provide value-added information in this study. The data were obtained by studying and using data related to the research topic. In this study, the data used in relation to the socialization patterns of taxes that exist in the Tax Office of East Java III.

Carrying out research activities required tools in the form of research instruments selected and used by the researcher in their activities to be systematic and facilitated by it (Arikunto, 2010). Research instrument is a tool used at the time of research to be directed, running smoothly, and systematic. The research instruments of this are presented as follows:

- The researcher in which the researcher's knowledge and experience is associated with the pattern of socialization of personal income tax, media, compliance, and tax revenue; 
- Observation Guidance by utilizing literature related to the socialization of personal income tax and existing regulations related to the media concerned;

- Field notes by taking notes on what occur in the field as well as copies of documents and archives in order to obtain the necessary data in the research.

Data Analysis, Validity, and Reliability. Content analysis was used to see how the content correlates from one source to another (Lofland; Snow; Anderson; and Lofland 2006: 2). Thus, it can obtained data on self-evaluation of both tax officers and taxpayers, the environmental picture, background informants of both taxpayers and tax officials, the matrix and solutions to map the socialization patterns and information systems referring to the purpose of tax office and taxpayers in compliance with the regulations for the optimization of tax revenues. Qualitative data also need to be verified by using internal validity and its construct and reliability (Creswell, 1994: 158) by using source triangulation and technique triangulation.

Data analysis, according to Gay (2006: 480), is the effort of a qualitative research to summarize data collected accurately and reliably. This is the typical presentation of research findings. Creswell (2014) provides six stages in the process of data analysis including:

1. Processing data and preparing data for analysis. This step includes interview transcription scanning material, typing field data, selecting and organizing data based on information sources;

2. Reading the entire data by reflecting on the overall meaning and giving marginal notes about common ideas obtained;

3. Analyzing more details by coding data. Creswell (2014) quotes Bogdan and Biklen in the coding stages: Context settings and context; Subject perspectives; The subjects' tendency to think of about others; Code process; Activity code; Code of strategy; Code of relation and social structure;

4. Applying the coding process to describe these settings, people, categories and themes to be written in narrative or qualitative reports;

5. Interpreting data.

\section{RESULTS AND DISCUSSION}

Base Erosion and Profit Shifting become a problem in the scope of tax globally because Base Erosion means a reduction in tax revenue that threatens the tax authorities and taxation justice in many countries by utilizing profit shifting. The BEPS issue shows that there are deficiencies in the inter-state taxation laws that rely heavily on double taxation (P3B) agreements, also known as tax treaties governing taxation rights between countries and many refer to the tax treaty model issued by the OECD. BEPS also indicates a shortage on domestic tax regulations in governing international taxation including rules on tax avoidance (anti-avoidance rule) and the transfer pricing rules.

BEPS report from the OECD reveals the key of BEPS issues:

- International Mismatches in terms of determining the character of entities and instruments;

- Implementation of the concept of tax treaty on profits from the delivery of goods and digital services;

- Treat taxes on financial transactions such as lending between companies;

- Transfer pricing is primarily of transfer of risk and intangible goods, artificial splitting of rare asset ownership or transactions on independent firms;

- The effectiveness of tax avoidance rules such as anti-avoidance rule, controlled foreign corporation, thin capitalization to prevent the abuse of tax treaty (treaty abuse);

- Availability of harmful preferential regimes (OECD 2015 Final Report).

However, the practice of BEPS can also be carried out because of the practice of hybrid Mismatches by implementing different transactions by each country to avoid tax and providing Special purpose entities (SPE) allowing the MNCs to transfer profits to other 
countries (Love, P 2013). This practice ultimately leads to unfair and competitive tax and inefficient allocation of funding sources. Furthermore, BEPS practices will impact on the loss or exclusion of potential revenues accepted by Jurisdiction / Country.

Currently, there are many countries in the world either G-20 Members or European Union (EU) which impose a normal/high tax rate (non-low tax jurisdiction). It makes them become the most vulnerable countries to be affected by the practice of BEPS by MNCs, so that these countries are ultimately the most emphatic in making the Rules or Policies in the fight against BEPS.

Table 1 - Tariff of Corporate Tax Rate of G-20 Member Countries

\begin{tabular}{|l|l|l|l|l|}
\hline \multirow{2}{*}{$\mathrm{n} / \mathrm{n}$} & \multirow{2}{*}{ Country } & Corporate Income & Capitals Gain & Branch \\
\cline { 3 - 5 } & & Tax Rate (\%) & Tax Rate (\%) & Tax Rate (\%) \\
\hline 1 & Argentina & 35 & 35 & 35 \\
\hline 2 & Australia & 20 & 30 & 30 \\
\hline 3 & Brazil & 15 & 15 & 15 \\
\hline 4 & Canada & 15 & 7.5 & 15 \\
\hline 5 & China & 25 & 25 & 25 \\
\hline 6 & France & $331 / 3$ & $0 / 15 / 331 / 3$ & $331 / 3$ \\
\hline 7 & Germany & 15 & 15 & 15 \\
\hline 8 & Indonesia & 25 & - & - \\
\hline 9 & India & 30 & 20 & 40 \\
\hline 10 & Italy & 27.5 & $1.37 / 27.5$ & 27.5 \\
\hline 11 & Japan & 25.5 & 25.5 & 25.5 \\
\hline 12 & Republic of Korea & 22 & 22 & 22 \\
\hline 13 & Mexico & 30 & 30 & 30 \\
\hline 14 & Russia & $5 / 20$ & $5 / 20$ & $5 / 20$ \\
\hline 15 & Saudi Arabia & 30 to 85 & 20 & - \\
\hline 16 & South Africa & 28 & 18.65 & 28 \\
\hline 17 & Turkey & 20 & 20 & 20 \\
\hline 18 & United Kingdom & 24 & 24 & 24 \\
\hline s & United States & 35 & 35 & 35 \\
\hline 20 & European Union & 24 & 24 & 24 \\
\hline
\end{tabular}

Source: http://www.ey.com/GL/en/Services/Tax/Worldwide-Corporate-Tax-Guide-Country-list

The increasing number and pace of transactions in the global economic era demanding the mobility of goods, capital, labor and various input factors of production and also by considering the variety of tax rates imposed by OECD member countries can actually trigger a profit shifting activity which are taxed (tax activities). This phenomena require each country/ jurisdiction to make tax externalities in which each country create interaction strategy to formulate a tax policy aimed ultimately at collecting and moving capital to the country.

The process of establishing tax rates in a jurisdiction is usually by considering the existing tax competition. Tax competition happens because the country specifies tax rates by looking at the advantages and taxation of the allocation of its resources. Wilson (1999) and Leach (2007) state that, due to tax competition, the difference of tariffs in different regions low tax regions will receive capital flows while high tax regions will not receive capital flows.

The OECD has reviewed various BEPS-related studies and found evidence that there is an indirect link between imposing low tax rates and profit shifting by MNCs, as well as the fact that there are some countries that deliberately implement low tax rate regimes (low-tax jurisdiction) and take advantage of it. In addition, the OECD reported that OECD member countries are significantly affected by the practice of profit shifting by MNCs. When small countries imposing low tax rates obtain significant inflows of foreign direct investment (FDI) by thousands of percent of the country's total GDP, the OECD countries only obtain $36 \%$ of the country's total GDP.

Considering that phenomenon, every council in various countries has its own view in combating Base Erosion and Profit Shifting (BEPS) as reported in the article of The Russian Corporate World that the issue of the pros and cons in BEPS practice, according to the article, is due to the absence of direct impact the same for all countries on the practice of 
BEPS conducted by MNC. According to the article, there are differences in the Profit Shifting Practices conducted by MNCs in developed countries such as the United States and Western Europe with Russia and the Soviet Union and Eastern Europe. The realization is that MNCs in Russia mostly practice the transfer of assets and property they have to other countries in order to protect their property and assets, not their profits. Furthermore, in Russia, they usually place the holding company in another country, not a subsidiary as the MNCs do in Western countries.

Table 2 - Tax Review Related 15 Action issued by the OECD in combating the Base Erosion and Profit Shifting (BEPS)

\begin{tabular}{|c|c|c|c|}
\hline Action & Theme & Conclusion & $\begin{array}{l}\text { Form of } \\
\text { Recommendation } \\
\text { applied in Indonesia }\end{array}$ \\
\hline 1 & 2 & 3 & 4 \\
\hline 1 & $\begin{array}{l}\text { Addressing the } \\
\text { challenge of taxation } \\
\text { on digital transactions } \\
\text { (digital economy) }\end{array}$ & $\begin{array}{l}\text { How to help collecting VAT effectively and efficiently } \\
\text { (maximizing VAT eroded by digital transactions) } \\
\text { based on a country in which the consumer is a cross- } \\
\text { border business-to-consume transaction. OECD and } \\
\text { G-20 countries have agreed to monitor the } \\
\text { development and analysis of data to be available } \\
\text { from time to time. The international tax must be } \\
\text { observed whether it is ready to accept the challenge } \\
\text { of taxation because of the digital economy. }\end{array}$ & $\begin{array}{l}\text { Indonesia itself has } \\
\text { prepared Tax on E- } \\
\text { commerce } \\
\text { transactions and } \\
\text { Start-Ups that was } \\
\text { legalized in } 2017 .\end{array}$ \\
\hline 2 & $\begin{array}{l}\text { Overcoming or } \\
\text { neutralizing the } \\
\text { effects of hybrid } \\
\text { schemes of mismatch } \\
\text { arrangements }\end{array}$ & $\begin{array}{l}\text { The implementation of action } 2 \text { will facilitate the } \\
\text { convergence of national practice through domestic } \\
\text { treaty provisions to neutralize such arrangements. } \\
\text { Which will impact: } \\
\text { - Avoid double non taxation (by eliminating tax } \\
\text { benefits from incompatibility } \\
\text { - To end multiple expensive deductions into a } \\
\text { single expense } \\
\text { - This regulation shall preclude the use of such } \\
\text { agreements as a tool for BEPS without the } \\
\text { adverse effects of Cross Border Trade and } \\
\text { investment. }\end{array}$ & - \\
\hline 3 & $\begin{array}{l}\text { Strengthening } \\
\text { Controlled Foreign } \\
\text { Company (CFC) rules }\end{array}$ & $\begin{array}{l}\text { Strengthening the Controlled Foreign Companies' } \\
\text { (CFC) rules to prevent taxpayers from shifting its } \\
\text { revenues to subsidiaries abroad (foreign } \\
\text { subsidiaries). }\end{array}$ & $\begin{array}{l}\text { In terms of } \\
\text { strengthening the } \\
\text { CFC rules in } 2017 \text {, } \\
\text { Indonesia renewed } \\
\text { its Rule as stipulated } \\
\text { in FMD Number. } 107 \\
\text { of } 2017\end{array}$ \\
\hline 4 & $\begin{array}{l}\text { Preventing the } \\
\text { erosion of taxes } \\
\text { made through the } \\
\text { imposition of interest } \\
\text { charges and the } \\
\text { imposition of other } \\
\text { financial costs }\end{array}$ & $\begin{array}{l}\text { The general approach aims to ensure that the net } \\
\text { interest deductions on the entity will be directly linked } \\
\text { to the taxable income generated by its economic } \\
\text { activities and encourage improved coordination of } \\
\text { national regulations in this area. }\end{array}$ & - \\
\hline 5 & $\begin{array}{l}\text { Resolving more } \\
\text { costly tax practices } \\
\text { more effectively and } \\
\text { paying attention to } \\
\text { the transparency and } \\
\text { substance of the } \\
\text { transaction }\end{array}$ & $\begin{array}{l}\text { The adverse taxation of the examples of preferential } \\
\text { regimes and the absence of transparency makes this } \\
\text { action } 5 \text { finally creating a minimum standard of } \\
\text { whether there is a substantial activity in preferential } \\
\text { regimes. }\end{array}$ & - \\
\hline 6 & $\begin{array}{l}\text { Preventing the } \\
\text { misuse of P3B (treaty } \\
\text { abuse) }\end{array}$ & $\begin{array}{l}\text { There are minimal standards to prevent treaty abuse } \\
\text { including treaty shopping and new regulations that } \\
\text { provide security to prevent misuse of P3B and offer a } \\
\text { certain degree of flexibility on how to do so. }\end{array}$ & $\begin{array}{l}\text { This is also } \\
\text { reinforced by the new } \\
\text { P3B Regulations set } \\
\text { in PER 10/PJ/2017 to } \\
\text { emphasize the } \\
\text { Beneficial Owner } \\
\text { (BO). }\end{array}$ \\
\hline
\end{tabular}




\begin{tabular}{|c|c|c|c|}
\hline 1 & 2 & 3 & 4 \\
\hline 7 & $\begin{array}{l}\text { Preventing tax } \\
\text { evasion through the } \\
\text { use of rules on BUT }\end{array}$ & $\begin{array}{l}\text { The taxation agreement generally regulates the } \\
\text { business profits of a foreign company to be taxed in } \\
\text { the circumstances only if the company has a } \\
\text { permanent establishment (BUT) in the country } \\
\text { included in the tax treaty. It is important to determine } \\
\text { whether a Non Resident company must pay income } \\
\text { tax in another country. }\end{array}$ & $\begin{array}{l}\text { Indonesia's decisive } \\
\text { step is proven by the } \\
\text { issuance of the Over } \\
\text { The Top (OTT) } \\
\text { Regulations, the } \\
\text { Regulation requires } \\
\text { all foreign companies } \\
\text { providing OTT } \\
\text { content to establish a } \\
\text { Permanent Business } \\
\text { entity in Indonesia. }\end{array}$ \\
\hline $8-10$ & $\begin{array}{l}\text { Ensuring that the } \\
\text { transfer pricing } \\
\text { results are in line with } \\
\text { Value Creation }\end{array}$ & $\begin{array}{l}\text { Transfer Pricing Rules on the OECD and UN Tax } \\
\text { Conventions are used to determine the base of the } \\
\text { arm's length principle, including the transaction price } \\
\text { in the MNE group. } \\
\text { - Action } 8 \text { is more of an issue of transfer pricing } \\
\text { associated with transaction control involving } \\
\text { intangible assets, since intangible property has } \\
\text { been defined as hard-to-value. The misallocation } \\
\text { of profits generated by intangible goods has } \\
\text { contributed greatly to the BEPS practice, } \\
\text { Action } 9 \text {, the allocation of contract risk will be } \\
\text { enforced only if supported by the actual decision } \\
\text { maker and thereby controlling their risk, } \\
\text { - Action } 10 \text { will focus on other high-risk areas. }\end{array}$ & - \\
\hline 11 & $\begin{array}{l}\text { Creating methods for } \\
\text { collecting and } \\
\text { analyzing BEPS } \\
\text { related data and } \\
\text { steps to follow-up }\end{array}$ & $\begin{array}{l}\text { The new OECD analysis estimates, and recognizes } \\
\text { the complexity of BEPS as well as the limitations of } \\
\text { methodology and data, that the scale of global } \\
\text { corporate tax revenue losses ranges from } 100 \text { to } 240 \\
\text { billion USD per year. And for the future, it is expected } \\
\text { to improve economic analysis and BEPS monitoring } \\
\text { by requiring countries to improve their data } \\
\text { collection, compilation and system of analysis. }\end{array}$ & $\begin{array}{l}\text { Indonesia has issued } \\
\text { e-billing, AKASIA } \\
\text { system, and } \\
\text { simplification of HS } \\
\text { code on the } \\
\text { numbering of goods } \\
\text { related to Export- } \\
\text { Import. }\end{array}$ \\
\hline 12 & $\begin{array}{l}\text { Requiring disclosure } \\
\text { of tax planning } \\
\text { aggressively to the } \\
\text { Taxpayer }\end{array}$ & $\begin{array}{l}\text { The report of action } 12 \text { provides a modular } \\
\text { framework, that is the best practice used by countries } \\
\text { without mandatory disclosure rules that seek to } \\
\text { design an understanding that suits the needs of } \\
\text { those countries to obtain information early on an } \\
\text { aggressive or abusive tax planning scheme and for } \\
\text { its users. The recommendations in this report are not } \\
\text { representative of minimum standards and countries } \\
\text { are free to choose if they do not want to choose } \\
\text { whether to introduce the notion of taxpayer } \\
\text { disclosure. This framework is also intended for } \\
\text { reference to countries that already have their own } \\
\text { understanding, in order to improve the effectiveness } \\
\text { of the understanding. }\end{array}$ & - \\
\hline 13 & $\begin{array}{l}\text { Fixing the rules } \\
\text { regarding Transfer } \\
\text { Pricing } \\
\text { documentation }\end{array}$ & $\begin{array}{l}\text { The Action Report } 13 \text { contains a "three-tiered" } \\
\text { standard approach for transferring pricing, including } \\
\text { the country-by-country reporting minimum standards. } \\
\text { These minimum standards reflect a commitment to } \\
\text { establish a Common Temple for country by country } \\
\text { which reports consistently. }\end{array}$ & $\begin{array}{l}\text { Indonesia itself has } \\
\text { exposed Regulatory } \\
\text { Reform related } \\
\text { Documentation on } \\
\text { Transfer Pricing as } \\
\text { stipulated in PMK } \\
213 \text { / PMK.03 / } 2016\end{array}$ \\
\hline 1 & 2 & 3 & 4 \\
\hline 14 & $\begin{array}{l}\text { Making tax dispute } \\
\text { resolution } \\
\text { mechanisms more } \\
\text { effective }\end{array}$ & $\begin{array}{l}\text { Making the tax dispute resolution mechanism } \\
\text { becomes more effective and ensuring that minimum } \\
\text { standards are met and countries make further } \\
\text { progress to resolve their tax disputes. In addition, } \\
\text { large groups of countries have committed to rapidly } \\
\text { adopt binding provisions and arbitrations within their } \\
\text { tax treaties. }\end{array}$ & - \\
\hline
\end{tabular}




\begin{tabular}{|l|l|l|l|}
\hline 15 & $\begin{array}{l}\text { Developing } \\
\text { Multilateral } \\
\text { Instrument (MLI) to } \\
\text { BEPS Project can be } \\
\text { implemented }\end{array}$ & $\begin{array}{l}\text { The Action Report 15 discusses MLI's technical } \\
\text { feasibility of applying steps related to the BEPS } \\
\text { treaty and amending the bilateral tax treaty. This } \\
\text { proves that MLI is needed and feasible, and that } \\
\text { negotiations for such Instruments should be } \\
\text { immediately made and met. }\end{array}$ & $\begin{array}{l}\text { This year 2017 MLI } \\
\text { has been approved } \\
\text { and signed by } 68 \\
\text { Countries in OECD } \\
\text { Head Office Paris, } \\
\text { France. MLI is a } \\
\text { simultaneous } \\
\text { modification of tax } \\
\text { treaty arrangements, } \\
\text { synchronous and } \\
\text { efficient, without } \\
\text { going through a } \\
\text { bilateral negotiation } \\
\text { process. }\end{array}$ \\
\hline
\end{tabular}

Source: $h t t p: / / w w w . o e c d . o r g / c t p / b e p s-a c t i o n s . h t m$

Globalization requires global solutions and dialogue that can be drafted and transcended by the OECD and G-20 countries. The high level of interest of developing countries for their participation in the BEPS project should be addressed by the preparation of a more inclusive framework, which will continue to include international organizations and other regional tax organizations. Taking experience from the success of the Global Forum on Transparency and the Exchange of Information for Tax Purposes, in early 2016, the OECD and the G20 countries continued to collaborate to design and propose a more inclusive framework to support and monitor/supervise the implementation of the BEPS program, in which the country and its jurisdiction participated on the same mission.

This work will cover consideration of the manner in which the non-OECD and non-G20 countries and their jurisdiction can commit in agreement on standards and their implementation. This will withdraw the mandate of G20 Finance Ministers and Bank Central Governors as in the "Communique" published in Ankara on 5 September 2015: "... The effectiveness of the project will be determined by its wide spread and consistent implementation. We will continue to monitor the implementation of the BEPS project outcomes at global level, in particular, the exchange of information on cross-border tax rulings. We call on the OECD to prepare a framework by early 2016 with the involvement of interested non-G20 countries and Jurisdictions, particularly developing economies, on an equal footing...".

Furthermore, this research discusses about the $8^{\text {th }}$ and $10^{\text {th }}$ BEPS Action Plan on Transfer Pricing. Indonesia has implemented latest rules or policies in connection with the Recommendation of BEPS Action Plan, namely the Transfer Pricing, Transfer pricing Documentation, Advance Pricing Agreement (APA), the Mutual Agreement Procedure (MAP), and Automatic Exchange of Information where the effect of the BEPS practice carried out continuously will disrupt the country's fiscal continuity in order to finance the construction of the country. The common way or scheme carried out in BEPS practice is through transfer pricing and using the treaty shopping. Transfer Pricing in general is a company policy in determining the price of a transaction between the parties having a special relationship. Although the term transfer pricing is actually a neutral term, but in practice the term transfer pricing is often interpreted as an attempt to reduce taxes by shifting profits (profit shifting) or profit between companies in one group. By tax authorities, transfer pricing is considered an attempt to avoid taxes (tax avoidance) if the determination of the price in the inter-party transactions that are affected by a special relationship is performed not in accordance with the provisions of taxation (mispricing). In Indonesia, transfer pricing practices are actually allowed if the company does it in accordance with its regulations and also makes Transfer pricing Documentation in accordance with Indonesian tax laws. 


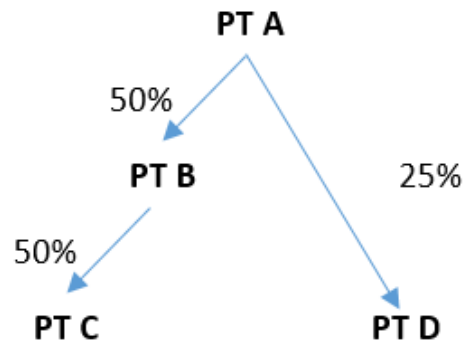

Figure 1 - Transfer Pricing Scheme according to Income Tax Law processed in 2017 (Source: data)

For example, Company A has $50 \%$ shares of Company B. The ownership of Company $A$ is a direct investment. If Company $B$ has $50 \%$ of Company $C$ shares, then Company $A$ as a shareholder of Company $B$ indirectly has an investment in Company $C$ of $25 \%$. Therefore, Company $A$, Company $B$ and Company $C$ are considered as related parties. If Company $A$ also has $25 \%$ of Company D shares, then Company B, Company C and Company D are considered to be related. Such ownership relationships may also occur between individuals and entities. PT means Perseroan Terbatas (PT) refers to Company.

The OECD recommends each country to complements domestic laws of each country with rules on transfer pricing. The OECD specifically publishes the OECD Transfer pricing Guidelines for Multinational Enterprises and Tax Administrations often called as the OECD Guidelines. The OECD Guidelines are intended to guide multinationals and tax authorities in resolving transfer pricing issues. Similarly, the United Nations (UN) has issued Practical Manual on Transfer pricing for Developing Countries which can be used as a guide for developing countries in handling transfer pricing.

The tax law in Indonesia, both the Income Tax Law and the VAT Law, contain instruments for the issue of transfer pricing (in the Income Tax Act, this provision is contained in Article 18 paragraph (3), while in the VAT Act, it is stipulated in Article 2 paragraph (1)). The taxation laws in Indonesia have included provisions on transfer pricing. In principle, both laws regulate that if the transaction is affected by a special relationship, then the fair price is used. Furthermore, the provision has also been supplemented by implementing regulations on the application of the principle of fairness and custom (arm's length principle) of business in the transactions between taxpayers with related parties.

In Indonesia, the practice of transfer pricing is considered legal or allowed if it is in accordance with the legislation on transfer pricing. In Indonesia, it is contained in PMK 213/PMK.03/2016 regarding transfer price documents. This regulation principally introduces three-level approach to the provision of documentation which is in line with the provisions of BEPS Action 13, the use of a threshold for document management, and to require documents to be made in Indonesian. This regulation also provides guidance on the party that is obliged to organize the documents, the information that should be included in the document, and when the documents should be available.

Under the current regulation, the taxpayer is only required to carry out a local transfer pricing document as the basis for applying the fairness principle and business practice on the transaction with the related party. PMK 213 requires taxpayers to organize and store three levels of documents consisting of: Master Document; Local Documents; Report per Country.

With the adoption of BEPS, OECD and other G20 countries as well as developing countries following these developments will be pioneers in modern International Taxation where profit will be taxed by economic activity and value creation. But, now is the time to pay attention to the challenges ahead of supporting the implementation of consistent and clear change recommendations, monitoring the impact of double non-taxation and double taxation, and designing a more inclusive framework to support the implementation and performing further monitoring activities (observation). 
Table 3 - Summary of Provisions in the Scope of Master Documents and Local Documents

\begin{tabular}{|c|c|c|}
\hline \multicolumn{2}{|l|}{ Terms } & Main Point \\
\hline \multicolumn{2}{|c|}{ Master Documents and Local Documents } & ("Document of transfer price") \\
\hline \multicolumn{2}{|c|}{$\begin{array}{l}\text { Coverage } \\
\text { A Taxpayer conducting transactions with a related party } \\
\text { affecting any of the following thresholds/conditions that is } \\
\text { required to prepare a transfer price document }\end{array}$} & \multirow{7}{*}{$\begin{array}{l}\text { This regulation has superseded the } \\
\text { determination of existing thresholds based on } \\
\text { "each transaction opponent for each year" with } \\
\text { thresholds perceived by gross circulation or the } \\
\text { type of transaction or jurisdiction of the } \\
\text { counterparty. } \\
\text { This Regulation does not specifically mention } \\
\text { exceptions to domestic transactions excluded } \\
\text { from the obligation to apply the principle of } \\
\text { fairness and business custom (depending on } \\
\text { certain circumstances) governed by current } \\
\text { regulations. } \\
\text { Thresholds must be calculated based on the } \\
\text { previous tax year. For example, the threshold } \\
\text { for fiscal year } 2016 \text { will be based on the values } \\
\text { of the } 2015 \text { tax year. } \\
\text { The taxpayer should review the applicable } \\
\text { corporate income tax rate from the jurisdiction in } \\
\text { which the related party (which is the opposite of } \\
\text { the transaction) is located to assess the } \\
\text { obligation to prepare the transfer pricing } \\
\text { document. } \\
\text { The presence of gross circulation, PMK } 213 \text { in } \\
\text { general, provides an exception to small and } \\
\text { medium taxpayers in connection with free } \\
\text { administration of documentation preparation. } \\
\text { However, the threshold aims to include more } \\
\text { transactions need to be documented. }\end{array}$} \\
\hline ITEM & Threshold & \\
\hline $\begin{array}{l}\text { Gross circulation in } \\
\text { the previous tax } \\
\text { year }\end{array}$ & $\begin{array}{l}\text { More than IDR } 50,000,000,000 \text { (fifty } \\
\text { billion rupiahs) }\end{array}$ & \\
\hline $\begin{array}{l}\text { Transaction } \\
\text { tangible goods in } \\
\text { the previous tax }\end{array}$ & $\begin{array}{l}\text { More than IDR 20,000,000,000 } \\
\text { (twenty billion rupiahs) }\end{array}$ & \\
\hline $\begin{array}{l}\text { OR } \\
\text { Services, royalties, } \\
\text { interest or other } \\
\text { transactions in the } \\
\text { previous tax year }\end{array}$ & $\begin{array}{l}\text { More than IDR } 5,000,000,000 \text { (five } \\
\text { billion Rupiah) }\end{array}$ & \\
\hline $\begin{array}{l}\text { Transactions with } \\
\text { related parties } \\
\text { located in } \\
\text { jurisdictions with tax } \\
\text { rates lower than in } \\
\text { Indonesia (currently } \\
25 \% \text { ) }\end{array}$ & There is no threshold & \\
\hline \multicolumn{2}{|c|}{$\begin{array}{l}\text { In addition, a Taxpayer who qualifies as a Holding Entity of a } \\
\text { Business Group that records consolidated gross turnover of } \\
\text { IDR } 11,000,000,000,000 \text { (one trillion Rupiah) is also required } \\
\text { to prepare a Transfer Price Document. } \\
\text { Under the terms of the tax year prior to covering a period of } \\
\text { less than } 12 \text { months, gross circulation or transactions with } \\
\text { related parties shall be calculated by annually. } \\
\text { For bookkeeping in currencies other than Rupiah, the } \\
\text { monetary value of the threshold shall be calculated using the } \\
\text { rate set by the Minister of finance for tax calculation at the end } \\
\text { of the tax year. } \\
\text { This Regulation clearly states that although the Taxpayer does } \\
\text { not meet the threshold of preparing the transfer price } \\
\text { document, the taxpayer shall still comply with the principle of } \\
\text { fairness and custom, the business of transactions with related } \\
\text { parties. }\end{array}$} & \\
\hline
\end{tabular}

Source: $h t t p s: / / w w w 2 . d e l o i t t e . c o m / c o n t e n t / d a m / D e l o i t t e / i d / D o c u m e n t s / t a x / i d-t a x-a l e r t-b a-j a n 2017 . p d f$

The practice of Base Erosion and Profit Shifting is a problem for developing countries and countries that apply High Tax Rate (Non Tax Jurisdiction). There is a great deal of evidence that multinational corporations deliberately avoid their tax obligations by transferring or making shell companies to other countries with a lower or even zero tariff. One example of endemic tax avoidance is a Google case. The Indonesian government in 2015 tried to uncover and hold accountable for losses incurred by the company. For the year of 2015 , only Internet giant in initiated by the United States must pay taxes more than US \$ 400 Million or equivalent to IDR 5.2 Trillion if proven to avoid taxes in the country (Source: www.beritasatu.com, https: / /finance.detik.com). Whether like it or not, good or bad, but in fact BEPS can erode a country leak and cause the government to lose the potential of tax revenues, especially those originated from corporate taxes. Considering the impact of tax planning carried out by Google that has led to aggressive tax planning and tax avoidance since Google does not only avoid tax in a country but also in other countries. Alphabet Inc, 
the holding company of Google also performed tax evasion efforts because similar cases also occurred in the UK, France, Italy and Spain.

However, the problem of BEPS cannot be merely seen from the negative side, because the complexity of the problem sometimes makes the opposite side to be not criticized maximally. If red flags are drawn, usually BEPS Practices are mostly carried out on Corporate Income Tax (especially in developing countries), in an interview conducted by DDTCNews to TP Ostwal, a cum practitioner of Indian tax academics recently appointed by the United Nations as one of the expert on development method of Transfer pricing for developing countries expresses different opinions. He said that when it is reviewed carefully the BEPS Practice has nothing to do with the income tax of a county agency but more to the culture and corporate behavior.

Companies that have bad behavior and management tend to do aggressive tax planning that can lead to tax evasion. Because before BEPS issues have been lifted and criticized and studied by various developing countries, many companies are doing tax evasion by finding the gaps in other countries where tax law is weak or the rate is low. As commonly known that BEPS is not a simple matter, the complexity of the problem is not only due to friction or non-diversity of taxation laws among different countries but also because of the different interests of the inter-countries and the business objectives.

\section{CONCLUSION}

Companies that have bad behavior and management tend to do aggressive tax planning that can lead to tax evasion. Because before BEPS issues appeared, criticized and studied by various developing countries, many companies are performing tax evasion by finding the gaps in other countries where the tax law is weak or the rate is low. As commonly known that BEPS is not a simple matter, the complexity of the problem is not only due to friction or non-diversity of taxation laws among different countries but also because of the different interests of the inter-countries and the business objectives.

There needs to be a synergy between government and taxpayers in understanding BEPS Action and in-depth study on the implementation in developing countries. Developing Countries with various forms of business and culture certainly cannot be accommodated with one standard of BEPS Action.

\section{REFERENCES}

1. Aeny, S. N. 2017. Senior Manager Transfer Pricing DDTC Raih Gelar LLM Int. Tax di Austria. Retrieved from http://news.ddtc.co.id/artikel/10340/berita-dari-vienna-seniormanager-transfer-pricing-ddtc-raih-gelar-Ilm-inttax-di-austria/ on July 9, 2017.

2. "Aktivitas Ekonomi Global dan Peran OECD". 2017. Retrieved from https://www.kemenkeu.go.id/sites/default/files/artikel\%20dan\%20opini\%20\%20base $\% 20$ erosion\%20profit\%20shifting.pdf, on November 14, 2017.

3. "Aksi BEPS Rugikan Negara Berkembang". 2016. Retrieved from https://news.ddtc.co.id/tp-ostwal-aksi-beps-rugikan-negara-berkembang-8630, on November 20, 2017.

4. Arifin, N. Z. 2017. Dalam kerangka kerjasama G-20 dan Implementasinya terhadap Indonesia. Retrieved from https://www.kemenkeu.go.id/kajian/beps-dalam-kerangkakerja-sama-g20-dan-implementasinya-kepada-indonesia, on November 14, 2017.

5. DDTCNews, R. 2016. Jalan Panjang Konsensus Pemajakan Ekonomi Digital. Retrieved from http://news.ddtc.co.id/artikel/8893/laporan-dari-mumbai-5-jalan-panjang-konsensuspemajakan-ekonomi-digital/ on July 9, 2017.

6. Hariannetral. 2013. Pengertian Globalisasi, Dampak Positif dan Negatif Globalisasi. Retrieved from http://hariannetral.com/2015/07/pengertian-globalisasi-dampak-positifdan-negatif-globalisasi.html on June 5, 2017.

7. Hines Jr., J. R. 2017. Policy forum: How serious Is the Problem of Base Erosion and Profit Shifting? Retrieved from http://repository.law.umich.edu/ on November 12, 2017. 
8. Idrisova, A 2013, The Pros and cons of calls for assets deoffshorization for business. The Russia Corporate World, Vol. 9.

9. "Local business taxation and competition for capital: the choice of the tax rate". Retrieved from https://papers.ssrn.com/ on November 22, 2017.

10. Love, P. 2013. What is BEPS and how can you stop it? OECD Insights, Paris.

11. "Memahami arti 'Treaty Shopping". 2017. DDTCNews. Retrieved from http://news.ddtc.co.id/ on November 14, 2017.

12. Ngantung, Y. W. 2016. Tantangan Perpajakan Ekonomi Global. Retrieved from http://news.ddtc.co.id/artikel/8806/analisis-pajak-internasional-tantangan-perpajakanekonomi-digital/ on July 9, 2017.

13. "Perbandingan pola tax competition di ASEAN dan Uni Eropa". Retrieved from http://www.ortax.org/ortax/?mod=issue\&page=show\&id=60 on November 22, 2017.

14. Visaro, D. 2017. Begini Cara dan Tantangan dalam Mengukur BEPS. Retrieved from http://news.ddtc.co.id/artikel/9472/pengukuran-dampak-beps-begini-cara--tantangandalam-mengukur-beps/ on July 5, 2017.

15. Wibowo, I. 2010. Negara Centeng. Yogyakarta: Penerbit Kanisius.

16. Wol. 2002. Globalisasi Harapan dan Kekhawatirannya. Retrieved from https://wol.jw.org/id/wol/d/r25/lp-in/102002361\#h=5 on July 5, 2017. 